\title{
HAEMATOLOGICAL AND GILL RESPONSES IN PARASITIZED TILAPIA FROM VALLEY OF TIJUCAS RIVER, SC, BRAZIL
}

\author{
Tatiana Maslowa Pegado de Azevedoํㅜㄹ Maurício Laterça Martinss ${ }^{1 *}$; Fabiana Rizzi Bozzo ${ }^{2}$; \\ Flávio Ruas de Moraes² \\ ${ }^{1}$ UFSC - Depto. de Aqüicultura, C.P. 476 - 88040-900 - Florianópolis, SC - Brasil. \\ ${ }^{2}$ UNESP - Centro de Aqüicultura - Depto. de Patologia Veterinária - 14884-900 - Jaboticabal, SP - Brasil. \\ *Corresponding author <mlaterca@cca.ufsc.br>
}

\begin{abstract}
In the State of Santa Catarina there is no information about haematological and parasitological characteristics of fish maintained in feefishing operations and manured ponds. This work compared the haematological characteristics of Nile tilapia parasitized or not, captured in a property situated in Nova Trento, SC, Brazil, between August 2003 and July 2004. During the studied period, the water temperature, $\mathrm{pH}$, dissolved oxygen, alkalinity, ammonia and transparency were measured. Ten fish were collected monthly either in a feefishing or in a pond receiving pig manure, and anesthetized with benzocaine solution for haematological, parasitological and histopathological exams. From a total of 360 analyzed fish, 64 (17.8\%) were parasitized with Cichlidogyrus sclerosus and Cichlidogyrus sp. (Monogenoidea: Ancyrocephalidae), 20 (5.5\%) with Trichodina sp. (Protozoa: Ciliophora), and four (1.1\%) with Lamproglena sp. (Crustacea: Lernaeidae). The total number of erythrocytes, thrombocytes and leucocytes, glucose rate and the percentages of hematocrit, lymphocytes, monocytes and neutrophils did not show relation with parasitism. Histopathological analysis showed moderate hyperplasia and absence of congestion. The low level of parasitism found in the animals was not responsible for haematological alterations.
\end{abstract}

Key words: Oreochromis niloticus, Santa Catarina, parasitism, haematology, histopathology

\section{RESPOSTAS HEMATOLÓGICA E BRANQUIAL DE TILÁPIA PARASITADA DO VALE DO RIO TIJUCAS, SC, BRASIL}

\begin{abstract}
RESUMO: No Estado de Santa Catarina não existe informação sobre características hematológicas e parasitológicas que compare peixes mantidos em pesque-pague e com dejetos de suínos. Este trabalho estudou as características hematológicas da tilápia do Nilo parasitada ou não, capturada numa propriedade em Nova Trento, SC, Brasil, entre agosto de 2003 e julho de 2004. Durante o período a temperatura da água, $\mathrm{pH}$, oxigênio, alcalinidade e transparência foram medidos. Dez peixes foram mensalmente coletados no pesque-pague e num viveiro que recebia dejetos de suínos, anestesiados com benzocaína para análise hematológica, parasitológica e histopatológica. De 360 animais analisados, 64 (17,8\%) estavam parasitados com Cichlidogyrus sclerosus e Cichlidogyrus sp. (Monogenoidea: Ancyrocephalidae), 20 (5,5\%) com Trichodina sp. (Protozoa: Ciliophora) e quatro (1,1\%) com Lamproglena sp. (Crustacea: Lernaeidae). O número total de eritrócitos, , trombócitos e leucócitos, a taxa de glicose, os percentuais do hematócrito, linfócitos, monócitos e neutrófilos não alteraram com o parasitismo. A análise histopatológica mostrou moderada hiperplasia e ausência de congestão. O baixo nível de parasitismo não foi responsável por alterações hematológicas.

Palavras-chave: Oreochromis niloticus, Santa Catarina, parasitismo, hematologia, histopatologia
\end{abstract}

\section{INTRODUCTION}

Aquaculture in Brazil has attracted the attention of producers and owners to the activities of rearing, fry production, and sport fishing. Its direct relation with job generation and wide economic relation with other activities has generate income of U\$ 200 million, and more than 300,000 workers directly involved (Kitamura et al.,
2002). As a result of the development of Aquaculture in the last 10 years, infectious and parasitic diseases outbreaks have occurred (Martins et al., 2002).

Parasitized fishes may present significant changes in their haematological and physiological characteristics (Ruane et al., 2000), affecting their development (Singhal et al., 1990; Ranzani-Paiva \& SilvaSouza, 2004a,b). In the United States alone, parasitic 
diseases of farmed fish caused in 1989 an economic loss estimated at US\$ 11.5 million (Klesius \& Rogers, 1995). Damage caused on the host depends on parasite species, type of injury in the host tissue, number of parasites and the health status of the host (Tavares-Dias et al., 1999a).

In Brazilian species, haematological changes have been caused by Argulus Müller 1785 (RanzaniPaiva et al., 1987; 1989; Tavares-Dias et al., 1999b); protozoan, Monogenoidea, copepods and Hirudinea (Ranzani-Paiva et al., 1997); Monogenoidea, Ichthyophthirius multifilis Fouquet 1876, Trichodina Ehrenberg 1830, Piscinoodinium pillulare (Schäperclaus 1954), Lernaea cyprinacea Linnaeus 1758 (Tavares-Dias et al., 1999a; Silva-Souza et al., 2000); Monogenoidea, nematodes, acanthocephalans and ergasilids (Ranzani-Paiva et al., 2000) and anisakids (Martins et al., 2004b).

This work compared the haematological characteristics of Nile tilapia, parasitized or not with ectoparasites, in a property situated in Nova Trento, SC, Brazil. Histopathological analysis of the gills from fish maintained with pig manure and in feefishing operation was performed.

\section{MATERIAL AND METHODS}

From August 2003 through July 2004, ten $O$. niloticus $(28 \pm 0.6 \mathrm{~cm}$ total length; $420 \pm 35 \mathrm{~g}$ mean body weight) were captured monthly by net in two ponds, in a fish farm situated in Nova Trento (Lat. $27^{\circ} 17^{\prime} 09^{\prime \prime} \mathrm{S}$, Long. $\left.48^{\circ} 55^{\prime} 47^{\prime \prime} \mathrm{W}\right)$, SC, Brazil. The animals from feefishing ponds were fed with commercial diet and the others were maintained in ponds with pig manure as main feed source. During the period, the water temperature was measured with bulb termometer, dissolved oxygen with oxymeter "YSI-Mod.55", $\mathrm{pH}$ with electronic peagameter Thermo Orion, alkalinity by colorimetric method and transparency with Secchi disc. A sample of $250 \mathrm{~mL}$ of water from the ponds was frozen for ammonia analysis according to Koroleff (1976).

After sedation with benzocaine solution ( $1 \mathrm{~g}$ $\left.10 \mathrm{~L}^{-1}\right)$, the blood was withdrawn from the caudal vein into a syringe containing a drop of $10 \%$ EDTA solution (approved by the Ethic Committee - CEUA n ${ }^{\circ}$ $23080.027275 / 2004-85 /$ UFSC). This blood was utilized to measure hematocrit (Goldenfarb et al., 1971); erythrocyte number in a Neubauer chamber; glucose (Accu-Chek Advantage 2 Roche); leucocyte and thrombocyte number by indirect method (Martins et al., 2004a), and differential counting of leucocytes by using the combination of Giemsa/May-Grunwald staining (Rosenfeld, 1947), in which a hundred cells were counted for the establishment of each cell contents.
After blood collection, parasitological exam consisted of scraping of body mucus and smears of organs for parasite evaluation. The gills were removed, placed in a flask with water at $55^{\circ} \mathrm{C}$ for slackness of Monogenoidea for one hour, shaked and fixed in 5\% formalin solution. After that, in the laboratory the gills were carefully observed for counting and presence of lernaeid crustaceans in the gill archs. Prevalence and mean intensity was calculated according to Bush et al. (1997).

For histopathological analysis, small pieces of tissue were fixed in $10 \%$ buffered formalin solution and embedded in paraffin. Cross sections $(6 \mu \mathrm{m})$ stained with haematoxilin and eosin were observed under microscope. The results were analyzed by Spearman's (rs) test $(\alpha=0.05)$ (Siegel, 1975) and the ANOVA F statistic for analysis of variance. The haematological analysis was done from the total mean of the blood variables during the whole period in parasitized and non-parasitized fish.

\section{RESULTS AND DISCUSSION}

No difference between the aquatic parameters of the feefishing lakes and manured ponds was observed (Table 1). Water temperature was lower in August 2003, May, June and July 2004, and higher in December 2003, January and February 2004. The total mean values of dissolved oxygen concentration and the water transparency were slightly lower in the manured pond than in the feefishing lakes.

During the studied period, water quality was adequate for tilapia maintenance. The lowest dissolved oxygen concentration of the manured pond ( 3.1 to 3.8 $\left.\mathrm{mg} \mathrm{L}^{-1}\right)$ and slightly acid $\mathrm{pH}$ (4.8 to 6.5$)$ probably resulted from high organic matter concentration and intermittent water flow, as already observed by Allabaster \& Lloyd (1982). Lower transparency of water of the manured pond was evident when compared to that of feefishing lake, differing from the findings of Sipaúba-Tavares et al. (1994), but similar to that related by Eler et al. (2001). In this study the presence of high contents of algae was directly related to nutrient input. Despite the low dissolved oxygen observed in the early morning, no mortality was reported, probably because the region's low water temperature avoided toxic substances liberation from organic matter. The oxygen concentration in the feefishing lake was similar to that reported by Tavares-Dias et al. (2001) in São Paulo State. However, a slight variation of $\mathrm{pH}$ during the whole period and the oxygen concentration between August 2003 and March 2004 corroborated the findings of Schalch (2002) for feefishing lakes in São Paulo State. 
From a total of 120 examined fish, 35 (29.2\%) were parasitized. Two (1.6\%) with Trichodina sp. (Protozoa: Ciliophora); 16 (13.3\%) with Cichlydogyrus Paperna 1960 and Cichlydogyrus sclerosus Paperna and Thurston 1969 (Monogenoidea: Dactylogyridae) on body mucus and gills, with mean intensity 4.2 (2.0 to 14.6$)$, being three $(2.5 \%)$ with only one $C$. sclerosus in the gills and four $(3.3 \%)$ were parasitized by Lamproglena sp. (Crustacea: Lernaeidae) in the gill archs with mean intensity 1.5 (1.0 to 2.0$)$. Table 2 shows the number of parasitized fish in each month of sampling, as well as their respective prevalence rates of Monogenoidea and Trichodina sp. in fish from feefishing and manured pond.

No difference on the haematological characteristics between parasitized and non-parasitized fish (Table 3) was recorded. It was observed slight decreasing of the erythrocyte number and hematocrit percentage in parasitized animals. Glucose rate, in this case, was not influenced by parasitism. In the differential

Table 1 - Aquatic characteristics of feefishing lakes (FF) and manured ponds (PM) in a facility situated in Nova Trento, SC, Brazil.

\begin{tabular}{|c|c|c|c|c|c|c|c|c|c|c|c|c|}
\hline \multirow[t]{3}{*}{ Months } & \multicolumn{2}{|c|}{ Temperature } & \multicolumn{2}{|c|}{ Oxygen } & \multicolumn{2}{|c|}{$\mathrm{pH}$} & \multicolumn{2}{|c|}{ Ammonia } & \multicolumn{2}{|c|}{ Alkalinity } & \multicolumn{2}{|c|}{ Transparency } \\
\hline & \multicolumn{2}{|c|}{$-\ldots-{ }^{\circ} \mathrm{C}-\ldots$} & \multicolumn{2}{|c|}{-.-- mg L $\mathrm{L}^{-1} \ldots$} & \multirow[b]{2}{*}{$\mathrm{FF}$} & \multirow[b]{2}{*}{ PM } & \multicolumn{4}{|c|}{ - mg L ${ }^{-1} \ldots \ldots$} & \multicolumn{2}{|c|}{$-\ldots-1 \mathrm{~cm}-\ldots$} \\
\hline & FF & PM & $\mathrm{FF}$ & PM & & & $\mathrm{FF}$ & PM & $\mathrm{FF}$ & PM & FF & PM \\
\hline Aug/03 & 19.3 & 18.2 & 9.3 & 5.7 & 7.1 & 7.0 & 0.5 & 0.5 & 20.0 & 40.0 & 25.0 & 4.0 \\
\hline Sep/03 & 19.0 & 20.0 & 8.3 & 6.8 & 7.0 & 6.0 & 0 & 0 & 25.0 & 20.0 & 22.0 & 7.0 \\
\hline Oct $/ 03$ & 22.5 & 22.7 & 8.5 & 5.8 & 6.5 & 6.5 & 0.108 & 0.098 & 30.0 & 20.0 & 14.0 & 16.0 \\
\hline Nov/03 & 24.4 & 25.3 & 4.0 & 3.8 & 6.5 & 6.0 & 0.103 & 0.107 & 30.0 & 30.0 & 18.0 & 12.0 \\
\hline Dec/03 & 28.1 & 28.8 & 5.8 & 3.8 & 6.5 & 6.5 & 0 & 0.072 & 30.0 & 30.0 & 17.0 & 22.0 \\
\hline $\mathrm{Jan} / 04$ & 26.3 & 26.9 & 6.4 & 4.1 & 5.1 & 4.8 & 0.032 & 0.048 & 30.0 & 30.0 & 15.0 & 18.0 \\
\hline $\mathrm{Feb} / 04$ & 25.4 & 25.1 & 7.8 & 5.9 & 7.4 & 7.8 & 0.135 & 0.194 & 30.0 & 30.0 & 10.0 & 18.0 \\
\hline Mar/04 & 32.0 & 27.6 & 6.5 & 5.5 & 5.6 & 5.4 & 0.136 & 0.151 & 20.0 & 25.0 & 22.0 & 9.0 \\
\hline Apr/04 & 24.0 & 24.5 & 3.8 & 3.1 & 6.0 & 5.5 & 0.313 & 0.073 & 50.0 & 80.0 & 20.0 & 12.0 \\
\hline May/04 & 19.2 & 19.0 & 3.5 & 3.1 & 5.1 & 5.1 & 0.043 & 0.199 & 40.0 & 30.0 & 20.0 & 10.0 \\
\hline Jun/04 & 17.3 & 18.0 & 3.8 & 3.2 & 6.2 & 6.3 & 0.160 & 0.348 & 30.0 & 30.0 & 10.0 & 10.0 \\
\hline $\mathrm{Jul} / 04$ & 18.3 & 18.7 & 4.3 & 3.8 & 6.5 & 6.7 & 0.131 & 0.143 & 30.0 & 30.0 & 10.0 & 10.0 \\
\hline Total mean & 23.0 & 22.9 & 6.0 & 4.5 & 6.3 & 6.1 & 0.116 & 0.143 & 30.0 & 33.0 & 17.0 & 12.0 \\
\hline
\end{tabular}

Table 2 - Prevalence rate of ectoparasites in Oreochromis niloticus maintained either in feefishing Lakes or manured pond in Nova Trento, SC, Brazil.

\begin{tabular}{|c|c|c|c|c|c|c|c|c|c|}
\hline \multirow{2}{*}{ Months } & \multicolumn{4}{|c|}{ Pond of feefishing } & \multicolumn{5}{|c|}{ Pond with pig manure } \\
\hline & $\mathrm{PF} / \mathrm{EF}$ & Monogenoidea & Trichodina & Lamproglena & $\mathrm{PF} / \mathrm{EF}$ & Monogenoidea & Trichodina & Lamproglena & Statistic \\
\hline & & - & 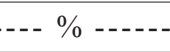 & - & & - & $---\%$ & - & \\
\hline Aug/03 & $5 / 5$ & 60 & 20 & 20 & $3 / 5$ & 60 & 0 & 0 & - \\
\hline $\mathrm{Sep} / 03$ & $5 / 5$ & 40 & 20 & 40 & $4 / 5$ & 60 & 0 & 20 & $P=0.410$ \\
\hline Oct/03 & $0 / 5$ & 0 & 0 & 0 & $0 / 5$ & 0 & 0 & 0 & - \\
\hline Nov/03 & $2 / 5$ & 40 & 0 & 0 & $1 / 5$ & 20 & 0 & 0 & $P=0.610$ \\
\hline $\mathrm{Dec} / 03$ & $1 / 5$ & 20 & 0 & 0 & $0 / 5$ & 0 & 0 & 0 & - \\
\hline $\mathrm{Jan} / 04$ & $1 / 5$ & 20 & 0 & 0 & $1 / 5$ & 20 & 0 & 0 & $P=0.610$ \\
\hline Feb/04 & $0 / 5$ & 0 & 0 & 0 & $0 / 5$ & 0 & 0 & 0 & $P=1.800$ \\
\hline Mar/04 & $0 / 5$ & 0 & 0 & 0 & $0 / 5$ & 0 & 0 & 0 & $P=0.610$ \\
\hline Apr/04 & $0 / 5$ & 0 & 0 & 0 & $0 / 5$ & 0 & 0 & 0 & - \\
\hline Mai/04 & $1 / 5$ & 20 & 0 & 0 & $0 / 5$ & 0 & 0 & 0 & $P=0.200$ \\
\hline Jun/04 & $0 / 5$ & 0 & 0 & 0 & $0 / 5$ & 0 & 0 & 0 & $P=0.410$ \\
\hline $\mathrm{Jul} / 04$ & $0 / 5$ & 0 & 0 & 0 & $0 / 5$ & 0 & 0 & 0 & - \\
\hline Total & $15 / 60$ & 33.3 & 20.0 & 30.0 & $9 / 60$ & 40.0 & 0 & 20.0 & - \\
\hline
\end{tabular}

PF: parasitized fish; EF: examined fish. 
counting of leucocytes, lymphocytes predominated followed by monocytes and neutrophils.

Haematological processes of anaemia have been observed in fish parasitized by cestodes (Sopinska, 1985). Omoregie (1998) and Omoregie \& Oyebanji (2002) registered haematological changes in tilapia exposed to oil and oxytetracycline, respectively. This shows that not only the presence of parasites but also altered environmental conditions may alter the haematology parameters of fish.

The discrete decreasing in the erythrocyte number and hematocrit in this study corroborated data reported by Sakanari (1984) for fish infected by anisakid nematodes; by Sopinska (1985) for carp parasitized by cestodes; by Ranzani-Paiva et al. (1987) for carp with Argulus sp.; by Yokoyama et al. (1996) for carp infected by Myxobolus artus Akhmerov 1960; by Tavares-Dias et al. (2002) for tilapia with I. multifiliis, and by Martins et al. (2004b) for Leporinus macrocephalus infected by anisakids. Decreased hematocrit in fish parasitized with Monogenoidea was also reported by Montero et al. (2004). The lack of alteration in the haematological characteristics was also observed by Tavares-Dias et al. (1999a) for Piaractus mesopotamicus parasitized with Argulus sp., by Tavares-Dias et al. (1999b) for P. mesopotamicus and L. macrocephalus with ectoparasites, by Ranzani-Paiva et al. (2000) for Schizodon borelli and Prochilodus lineatus with Monogenoidea, nematodes and acanthocephalans, and by Ranzani-Paiva \& Tavares-Dias (2002) for Mugil platanus with trichodinids, Monogenoidea, copepods and Hirudinea.

In contrast with our results, Ruane et al. (2000) observed increased number of erythrocytes and no alteration of hematocrit in parasitized trouts. The predominance of lymphocytes in the differential counting of leucocytes was similar to that observed by Silva-Souza et al. (2000) for fish parasitized with L. cyprinacea, but higher than the normally verified in tilapia (Ezzat et al., 1974; Lea Master et al., 1990; Alkahem, 1994; Ueda et al., 1997; Tavares-Dias \& Faustino, 1998; Tavares-Dias $\&$ Moraes, 2003). Histopathological analysis of gills did differ from Martins \& Romero (1996) who reported basal hyperplasia, necrosis and oedema in fish parasitized by Monogenoidea; from Longshaw et al. (2004) who reported moderate gill hyperplasia in fish parasitized by trichodinids, and Montero et al. (2004), who reported distortion of lamellar structure and lamellar fusion in fish parasitized by Monogenoidea. Hyperplasia observed in the gills of fish raised in the manured pond probably resulted from contact with suspended, particulate material (Figure 1).
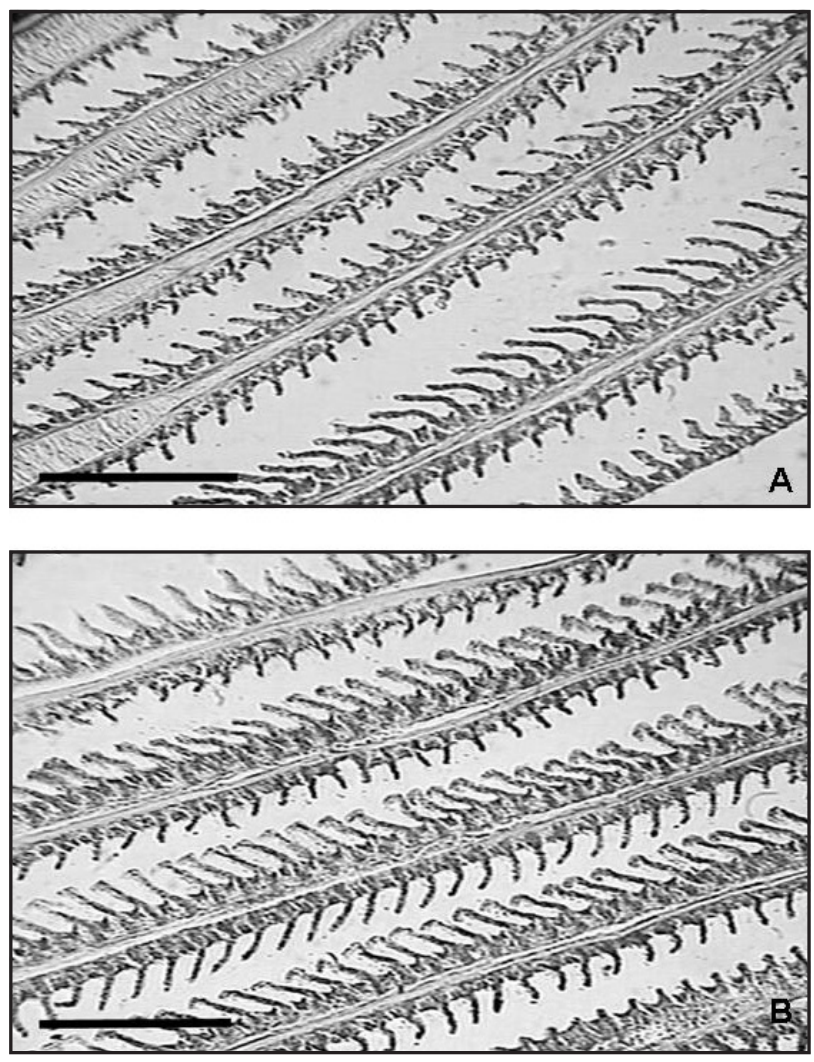

Figure 1 - Gill filaments of Nile tilapia from feefishing lakes (A) and manured ponds (B) in the State of Santa Catarina, Brazil. Scale bar $=100 \mu \mathrm{m}$.

Table 3 - Mean values $( \pm \mathrm{SD})$ and range of the haematological characteristics of Oreochromis niloticus parasitized or not, in Nova Trento, SC, Brazil.

\begin{tabular}{lccc}
\hline Variables & Non parasitized $(\mathrm{n}=85)$ & Parasitized $(\mathrm{n}=35)$ & Statistic \\
\hline Erythrocytes $\left(\mathrm{x} 10^{3} \mu \mathrm{L}^{-1}\right)$ & $1.500 \pm 340(820-1.630)$ & $1.070 \pm 390(880-1.580)$ & $P=0.220$ \\
Thrombocytes $\left(\mathrm{x} 10^{3} \mu \mathrm{L}^{-1}\right)$ & $31 \pm 22(18-33)$ & $35 \pm 23(20-38)$ & $P=0.950$ \\
Hematocrit (\%) & $42 \pm 15(20-46)$ & $33 \pm 9(22-44)$ & $P=0.508$ \\
Glucose $(\mathrm{mg} \mathrm{dL}-1)$ & $32 \pm 8(26-50)$ & $29 \pm 10(24-45)$ & $P=0.204$ \\
Total leucocytes $\left(\times 10^{3} \mu \mathrm{L}^{-1}\right)$ & $8.2 \pm 7.5(2.9-8.8)$ & $8.8 \pm 5.7(3.1-9.5)$ & $P=0.341$ \\
Lymphocytes (\%) & $96.6 \pm 1.5(95-97)$ & $97.4 \pm 1.1(95-98)$ & $P=0.947$ \\
Monocytes (\%) & $1.9 \pm 1.1(1.1-1.9)$ & $1.4 \pm 1.2(1.1-1.6)$ & $P=0.692$ \\
Neutrophils (\%) & $1.5 \pm 1.6(1.2-1.4)$ & $1.2 \pm 1.1(1.1-1.3)$ & $P=0.076$ \\
\hline
\end{tabular}


The number of ectoparasites in tilapia was not sufficient to induce changes in the haematological parameters. The conditions in which the fish are maintained vary between fish farms. The low level of parasitism and the lack of the gill response confirmed the influence of environmental factors, especially water temperature in parasite reproduction. Consequently, the diversity of parasitic fauna could vary depending on the host-parasite-environment equilibrium. Good management practices (Queiroz et al., 2004) must be applied to improve fish ponds productivity and to avoid parasite reproduction.

\section{ACKNOWLEDGEMENTS}

The authors thank Prof. Dr. Walter Antonio Boeger and Rogério Tubino Viana (UFPR, Departamento de Zoologia) by valorous collaboration in the Monogenoidea identification, the owners of "Pesque e Lazer Tridapalli" for supplying the fish and field support. To CAPES and CNPq for granting a Master Science and research scholarship respectively to the first and second authors. To Gastão Reis and Heloisa Laterça for revision of the manuscript translation.

\section{REFERENCES}

ALLABASTER, J.S.; LLOYD, R. Water quality criteria for freshwater fish. Rome: FAO/Butterworth Scientific, 1982. p.21-99.

ALKAHEM, H.F. The toxicity of nickel and the effects of sublethal levels on haematological parameters and behaviour of the fish, Oreochromis niloticus. Journal of University Kuwait Science, v.21, p.243-252, 1994.

BUSH, A.O.; LAFFERTY, K.D.; LOTZ, J.M.; SHOSTAK, W. Parasitology meets ecology on its own terms: Margolis et al. revisited. Journal of Parasitology, v.83, p.575-583, 1997.

ELER, M.N.; CECCARELLI, P.S.; BUFON, A.G.M.; ESPÍNDOLA, E.L.G. Mortandade de peixes (matrinxã, Brycon cephalus e pacu, Piaractus mesopotamicus) associada a uma floração de cianobactérias em pesque-pague, município de Descalvado, Estado de São Paulo, Brasil. Boletim Técnico do CEPTA, v.14, p.35-45, 2001.

EZZAT, A.A.; SHABANA, M.B.; FARGHALY, A.M. Studies on the blood characteristics of Tilapia zilli (Gervais) I. Blood cells. Journal of Fish Biology, v.6, p.1-12, 1974.

GOLDENFARB, P.B.; BOWYER, F.P.; HALL, E.; BROSIUS, E. Reproductibility in the hematology laboratory: the microhematocrit determination. American Journal of Clinical Pathology, v.56, p.3539, 1971.

KITAMURA, P.C.; QUEIROZ, J.F.; LOPES, R.B.; CASTRO, F.G.; BOYD, C.E. Environmental and economic assessment of feefishing in São Paulo State, Brazil. Journal of Applied Aquaculture, v.12, p.23-41, 2002.

KLESIUS, P.; ROGERS, W. Parasitisms of catfish and other farm-raised food fish. Journal of the American Veterinary and Medical Association, v.207, p.1473-1478, 1995.

KOROLEFF, F. Determination of nutrients. In: GRASSHOF, K. (Ed.) Methods of seawater analysis. Wenheim: Verlag Chemie, 1976. p.117-181.

LEA MASTER, B.R.; BROCK, J.A.; FUJIOKA, R.S.; NAKAMURA, R.M. Hematologic and blood chemistry values for Sarotherodon melanotheron and a red hybrid tilapia in freshwater and seawater. Comparative Biochemistry and Physiology, v.97A, p.525-529, 1990.
LONGSHAW, M.; GREEN, M.J.; FEIST, S.W. Histopathology of parasitic infections in greater pipefish, Syngnathus acus L., from an estuary in the UK. Journal of Fish Diseases, v.27, p.245-248, 2004.

MARTINS, M.L.; ROMERO, N.G. Efectos del parasitismo sobre el tejido branquial en peces cultivados: estudio parasitologico e histopatologico. Revista Brasileira de Zoologia, v.13, p.489-500, 1996.

MARTINS, M.L.; ONAKA, E.M.; MORAES, F.R.; BOZZO, F.R.; PAIVA, A.M.F.C.; GONÇALVES, A. Recent studies on parasitic infections of freshwater cultivated fish in the State of São Paulo, Brazil. Acta Scientiarum, v.24, p.981-985, 2002.

MARTINS, M.L.; PILARSKY, F.; ONAKA, E.M.; NOMURA, D.T.; FENERICK JR., J.; RIBEIRO, K.; MYIAZAKI, D.M.Y.; CASTRO, M.P.; MALHEIROS, E.B. Hematologia e resposta inflamatória aguda em Oreochromis niloticus (Osteichthyes: Cichlidae) submetida aos estímulos único e consecutivo de estresse de captura. Boletim do Instituto de Pesca, v.30, p.71-80, 2004a.

MARTINS, M.L.; TAVARES-DIAS, M.; FUJIMOTO, R.Y.; ONAKA, E.M.; NOMURA, D.T. Haematological alterations of Leporinus macrocephalus (Osteichthyes: Anostomidae) naturally infected by Goezia leporini (Nematoda: Anisakidae) in fish pond. Arquivo Brasileiro de Medicina Veterinária e Zootecnia, v.56, p.640-646, 2004b.

MONTERO, F.E.; CRESPO, S.; PADRÓS, F.; GÁNDARA, F.; DE LA GARCÍA, A.; RAGA, J.A. Effects of the gill parasite Zeuxapta seriolae (Monogenea: Heteraxinidae) on the amberjack Seriola dumerili Risso (Teleostei: Carangidae). Aquaculture, v.232, p.153163,2004

OMOREGIE, E. Changes in the haematology of the Nile tilapia Oreochromis niloticus Trewavas under the effect of crude oil. Acta Hydrobiologica, v.40, p.287-292, 1998.

OMOREGIE, E.E.; OYEBANJI, S.M. Oxytetracycline-induced blood disorder in juvenile Nile tilapia Oreochromis niloticus (Trewavas). Journal of the World Aquaculture Society, v.33, p.389-394, 2002.

QUEIROZ, J.F. de; NICOLELLA, G.; WOOD, C.W.; BOYD, C.E. Lime application methods, water and botton soil acidity in freshwater fish ponds. Scientia Agricola, v.61, p.469-475, 2004.

RANZANI-PAIVA, M.J.T.; SILVA-SOUZA, A.T. Hematologia de peixes brasileiros. In: RANZANI-PAIVA, M.J.T.; TAKEMOTO, R.M.; LIZAMA, M.A.P. (Ed.) Sanidade de organismos aquáticos. São Paulo: Editora Varella, 2004a. p.89-120.

RANZANI-PAIVA, M.J.T.; SILVA-SOUZA, A.T. Co-infestation of gills by different parasite groups in the mullet Mugil platanus Günther, 1880 (Osteichthyes, Mugilidae): effects on relative condition factor. Brazilian Journal of Biology, v.64, p.677-682, 2004b.

RANZANI-PAIVA, M.J.T.; TAVARES-DIAS, M. Eritrograma, relação viscerosomática, hepatosomática e esplenosomática em tainhas Mugil platanus Günther (Osteichthyes, Mugilidae) parasitadas. Revista Brasileira de Zoologia, v.19, p.807-818, 2002.

RANZANI-PAIVA, M.J.T.; VIEIRA, A.L.; ISHIKAWA, C.M. Análise dos constituintes do plasma sangüíneo da carpa, Cyprinus carpio, infestada por Argulus sp. Boletim do Instituto de Pesca, v.16, p.117$121,1989$.

RANZANI-PAIVA, M.J.; ISHIKAWA, C.M.; PORTELLA, M.C.; CELIBERTO, R.J. Hematologia da carpa comum Cyprinus carpio, infestada por Argulus sp. e após um tratamento com fosfato de 0,0dimetil-oxi-2,2,2,-tricloroetilo (Neguvon). Boletim do Instituto de Pesca, v.14, p.83-92, 1987.

RANZANI-PAIVA, M.J.T.; ISHIKAWA, C.M.; CAMPOS, B.E.S.; EIRAS, A.C. Haematological characteristics associated with parasitism in mullets, Mugil platanus Günther, from the estuarine region of Cananéia, São Paulo, Brazil. Revista Brasileira de Zoologia, v.14, p.329-339, 1997.

RANZANI-PAIVA, M.J.T.; SILVA-SOUZA, A.T.; PAVANELLI, G.C.; TAKEMOTO, R.M. Hematological characteristics and relative condition factor (Kn) associated with parasitism in Schizodon borelli (Osteichthyes, Anostomidae) and Prochilodus lineatus (Osteichthyes, Prochilodontidae) from Paraná River, Porto Rico region, Paraná, Brazil. Acta Scientiarum, v.22, p.515-521, 2000. 
ROSENFELD, G. Corante pancrômico para hematologia e citologia clínica. Nova combinação dos componentes do May-Grünwald e do Giemsa num só corante de emprego rápido. Memórias do Instituto Butantan, v.20, p.329-334, 1947.

RUANE, N.M.; NOLAN, D.T.; ROTLANT, J.; COSTELlO, E.J.; WEENDELLAR BONGA, S.E. Experimental exposure of rainbow trout Oncorhynchus mykiss (Walbaum) to the infective stages of the sea louse Lepeophtheirus salmonis (Kroyer) influences the physiological response to an acute stressor. Fish \& Shellfish Immunology, v.10, p.451-463, 2000.

SAKANARI, J.A. Effect of sublethal concentrations of zinc and benzene on striped bass, Morone saxatilis (Walbaum) infected with larval Anisakis nematodes. Journal of Fish Biology, v.24, p.553-563, 1984.

SCHALCH, S.H.C. Apreciação da fauna ictioparasitária em pesqueiro tipo pesque-pague do Município de Guariba - SP durante o período de abril de 1997 a março de 1999. Jaboticabal: UNESP/Centro de Aqüicultura, 2002. 102p. (Dissertação - Mestrado).

SIEGEL, S. Estatística não paramétrica. São Paulo: Mc Graw-Hill do Brasil, 1975. 350p.

SILVA-SOUZA, A.T.; ALMEIDA, S.C.; MACHADO, P.M. Effect of the infestation by Lernaea cyprinacea Linnaeus, 1758 (Copepoda, Lernaeidae) on the leucocytes of Schizodon intermedius Garavello \& Britski, 1990 (Osteichthyes, Anostomidae). Brazilian Journal of Biology, v.60, p.217-220, 2000.

SINGHAL, R.N.; JEET, S.; DAVIES, R.W. The effects of argulosissaprolehniasis on the growth and production of Cyprinus carpio. Hydrobiologia, v.202, p.27-31, 1990.

SIPAÚBA-TAVARES, L.H.; DURIGAN, J.G.; LIGEIRO, S.R. Caracterização de algumas variáveis limnológicas em um viveiro de piscicultura em dois períodos do dia. Revista UNIMAR, v.16, p.217227, 1994.

SOPINSKA, A. Effects physiological factors, stress, and disease on hematologic paramerters of carp, with a particular reference to the leukocyte patterns.III. Changes in blood accompanyng branchionecrosis and bothriocephalosis. Acta Ichthyologica et Piscatoria, v.15, p.141-165, 1985.
TAVARES-DIAS, M.; FAUSTINO, C.D. Parâmetros hematológicos da tilápia-do-Nilo Oreochromis niloticus (Cichlidae) em cultivo extensivo. Ars Veterinaria, v.14, p.254-263, 1998.

TAVARES-DIAS, M.; MORAES, F.R. Características hematológicas da Tilapia rendalli Boulenger, 1896 (Osteichthyes: Cichlidae) capturada em pesque-pague de Franca, São Paulo, Brasil. Bioscience Journal, v.19, p.103-110, 2003.

TAVARES-DIAS, M.; MARTINS, M.L.; KRONKA, S.N. Evaluation of the haematological parameters in Piaractus mesopotamicus Holmberg (Osteichthyes, Characidae) with Argulus sp. (Crustacea: Branchiura) infestation and treatment with organophosphate. Revista Brasileira de Zoologia, v.16, p.553-555, 1999a.

TAVARES-DIAS, M.; SCHALCH, S.H.C.; MARTINS, M.L.; SILVA, E.D.; MORAES, F.R.; PERECIN, D. Hematologia de teleósteos brasileiros com infecção parasitária. I. Variáveis do Leporinus macrocephalus Garavelo e Britski, 1988 (Anostomidae) e Piaractus mesopotamicus Holmberg, 1887 (Characidae). Acta Scientiarum, v.21, p.337-342, 1999b.

TAVARES-DIAS, M.; MARTINS, M.L.; MORAES, F.R. Fauna parasitária de peixes oriundos de "pesque-pague" do município de Franca, São Paulo, Brasil I Protozoários. Revista Brasileira de Zoologia, v.18, p.67-79, 2001

TAVARES-DIAS, M.; MORAES, F.R.; MARTINS, M.L.; SANTANA, A.E. Haematological changes in Oreochromis niloticus (Osteichthyes: Cichlidae) with gill ichthyophthiriasis and saprolegniosis. Boletim do Instituto de Pesca, v.28, p.1-9, 2002.

UEDA, I.K.; EGAMI, M.I.; SASSO, W.S.; MATUSHIMA, E.R. Estudos hematológicos em Oreochromis niloticus (Linnaeus, 1758) (Cichlidae, Teleostei) - Parte I. Brazilian Journal of Veterinary Research and Animal Science, v.34, p.270-275, 1997.

YOKOYAMA, H.; DANJO, T.; OGAWA, K. Hemorrhagic anemia of carp associated with spore discharge of Myxobolus artus (Myxozoa: Myxosporea). Fish Pathology, v.31, p.19-23, 1996.

Received June 20, 2005

Accepted March 08, 2006 